\title{
Implementation of citizen-centric e-Governance projects in
} Assam

\author{
Sri Keshabananda Borah. \\ Research Scholar, Political Science department Gauhati University, Assam, India.
}

\section{Introduction}

The term e-governance is of recent origin and there exist no standard definition since its conceptual understanding is still evolving. e-governance is beyond the scope of e-government. While e-government is defined as a mere delivery of government services and information to public using electronic means, egovernance allows direct participation of people in government activities. As such e-governance brings a new concept of citizenship both in terms of needs and responsibilities.

Electronic governance is the application of information Technology to process of government functioning to bring about new SMART governance. (Simple, Moral, Accountable, Responsive, Transparent). Dr. A.P.J Abul Kalam, the former president of India quotes, "Delivery of service to citizens is considered a primary function of the government. In a democratic nation over one billion people like India, e-governance should enable seamless access to information and seamless flow of information across the state and central government in the federal set up. No country has so far implemented and e-governance system for one billion people. It is a big challenge for us." E-governance promises a package of benefit to citizens by accelerating and automating government citizen interface, bring transparency in the functioning of the government and enabling democratization. E-governance develops new style of governance through by engaging citizen trust in the governance.

The UNESCO definition is, "E-governance is the public sector's use of information and communication technologies with the aims of improving information and service delivery, encouraging citizen participation in the decision making process and making government more accountable, transparent and effective. E-governance involves new style of leadership, new ways of debating and deciding policy and investment, new ways of accessing education, new ways of listening to citizens and new ways of organizing considered as a wider concept then e-government, since it can bring about a change in the way citizen's relate to governments and to each other. E-governance can bring forth new concepts of citizenship, both in terms of citizen's needs and responsibilities. Its objective is to engage, enable and empower the citizens." E-governance thus meant to understand a process where government to people and people to government connection regularly takes place and citizen obtain direct access to records, rules and information about entitlement that they need or want in their daily lives.

In the science of administration whether public or private the basic good is 'efficiency'. With the rapid expansion of public administration, the needed for public good and transparency in administration is extremely felt. This efficiency can be achieved only through good governance. Good governance is associated with efficiency, transparency, legitimacy, accountability and responsiveness. It is to be noted that all these important attributes constitutes e-governance. As the core basis of e-governance is to deliver a package of efficiency, time boundness, cost efficiency and client oriented service to the citizen. Therefore the ideal purpose of 'Good governance' can be achieved through e-governance.

The government of India has initiated e-governance project in the country in late 1990s. The union government has approved that national e-governance plan(NeGP) comprising of 27 Mission Mode Projects(MMPs), 9 central (MMPs), 11 state (MMPs), and 7 integrated MMPs to give a boost to e-governance initiatives in India. Department of information Technology (DIT) and Department of Administrative reforms and public grievances (DAR \& PG) has formulated National e-governance plan (NeGP) with a vision to "Make all public service accessible to the common man in his locality, through common service delivery outlets and ensure efficiency, transparency and reliability of such services at affordable costs to realize the basic needs of the common man." The second Administrative reform commission (ARC) titled 'promoting e-governance-The smart way forward' identified the needs for e-governance to bring government closer to its citizen (G2C).

\section{The Nine (9) mission Mode Projects under central government category are-} 1. MCA 21

This MMP is in its post implementation stage and is providing electronic services to the companies registered under the companies act for their related activities such as allocation and change of name, incorporation, online payment of registration charges, and change in address of registered office, viewing of 
public records and other related services. The benefits being made available to the citizens are continuously monitored.

\section{Pension}

The Pensioners' portal launched in March 2007 provides updated information on government pension rules and regulations, helps facilitating registration of pensioners' grievances, enables monitoring timely sanction of pension/gratuity, and maintains a database of pensioners and providing links to the websites of the Directorates of pensions and the agents of various states.

\section{Income Tax}

This MMP which is under implementation offers a set of 17 e-services of the Income Tax Department to the tax payers. Some of the e-services being offered include facility of downloading of various forms, online submission of application for PAN, e-filing of income Tax Returns, online payment of taxes, issues of refund through electronic clearance scheme (ECS) etc.

\section{Pasport, Visa and Immigration}

The implementation of Passport \&visa has streamlined the process for issuance of passport and other related service like providing efficient immigration services to people visiting India. The e-services being offered under the MMP include re-issue of Passport, issue of duplicate passport, change in name, passport status enquiry etc.The immigration services are in design and development phase.

\section{Central Excise}

The MMP is under implementation and is facilitating availability of e-services related to indirect taxation for industry, importers and exporters, inbound travelers etc.The important e-services being offered include e-filing of import and export documentation, electronic processing of declarations e-registration, epayment of customs duties etc.

\section{Banking}

The MMP which is being implemented by the banking industry aims at streamlining various e-services initiatives undertaken by individual banks.e-governance implementation is being done by bank concerned. The three components under this MMP are Mass payment System, Electronic central Registry and One India One Account for public sector banks.

\section{National ID/ UID (Unique identification Number)}

UID project is a planning commission initiatives proposes to-(a) create a central database of residents, initially of those above the age of 18 years(b)Generate a unique identification number for all the citizens. The UID is intended to provide a robust basis for efficient delivery of various social and welfare services to persons bellow the poverty line(BPL).It can also be used as the basis for identifying and authenticating a person's entitlement to government services and benefits through a single system rather than all government departments individually and independently investing and creating infrastructure, systems and procedures for verifying entitlement of residents under various schemes of government.

\section{E-office}

The government of India in reorganization of the long felt need for efficiency in government processes and service delivery mechanism has included e-office as a core Mission Mode Project (MMP) under NeGP.The Objectives are-

-To improve efficiency, consistency and effectiveness of government responses.

-To reduce turnaround time to meet the demands of the citizen charter.

-To reduce processing delays.

-To reduce transparency and accountability.

-To provide for effective resource management to improve the quality of administration.

\section{Insurance}

The MMP is an industry initiative (By Public sector insurance companies) and is in the conceptualization stage. The MMP aims at facilitating customer services, automating grievances redressal mechanism and creating a holistic database of insurance users. 


\section{The Eleven (11) state MMPs are- \\ 1. Land records}

The computerization of land records (CLR) is one of the earliest initiatives of e-governance in India, at the grass root level. I the pre NeGP phase, two schemes of the Ministry of Rural development-computerization of land records (CLR) and strengthening of revenue administration and updation of land records (SRA\&ULR) were being implanted. These are fully operational in 13 states. This project aims at-

-To ensure efficient, accurate, transparent delivery mechanism and conflict resolution in ownership.

-Providing electronic record of rights (POR) to land owners at nominal rates.

-Information empowerment of land owners.

-Value addition and modernization in land administration.

\section{Road Transport}

This MMP proposes to offer many e-services and some of its components are under implementation from the pre NeGP period. The MMP aims to induct technology in transport offices across India to offer vehicle registration, driving licenses and Smart Card baed RCs (Registration Certificates) to citizens. Out of total 763 RTOs, 486 have started offering vehicle registration services, while 440 RTOs are offering driving license related services.

\section{Agriculture}

The MMP aims at providing information regarding farm practices, market trends, agricultural and technical know-how and other related services to the firming community. The Directorate of marketing and inspection (DMI) successfully running an ICT project Agricultural Marketing Information system Network (AGMARKTET). AGMARKNET aims at creating an information network which will capture/ update information at various agricultural produce markets.

\section{Police}

The MMP aimed at facilitating the process of civil policing and law enforcement by utilizing ICT effectively. Under this project more than 1200 police stations were to be computerized which were expected to create an information base on crimes and criminals. Work is still going on for computerization of the remaining police station across the country.

\section{Treasuries}

This MMP aims at computerization of treasuries involving common set of standards for seamless integration of participating agencies. Some states like Uttarakhand, Mizoram and Karnataka achieved considerable progress.

\section{Municipalities}

The Municipalities MMPs aims at leverage ICT for sustained improvement in efficiency and effectiveness of delivery municipal services to citizens. This project aims at-

-To provide single window services to citizens on anytime anywhere basis.

-To increase the efficiency and productivity of urban local bodies.

-To provide timely and reliable management information relating to municipal administration for effective decision making.

\section{7. e-Districts}

This MMPs aims at electronic delivery of identified high volume citizens centric services at district and sub district level, those are not part of any other MMP. The MMP envisages leveraging and utilizing the three pillars of e- infrastructure namely state Data centre (SDC), State Wide Area Network (SWAN), and Common Service Centre (CSC) optimally to deliver public services electronically to citizens at their door steps. Some Specific objectives of e-Districts are-

-Reduce administrative burden and service fulfillment time $\&$ costs for the government, citizens and business. -Reducing number of visits of citizens to a government office for availing the services and thereby eliminating harassment.

-Reducing direct interaction of citizens with the government and encourage e-interaction and efficient communication through portal.

-Delivery of public services at district and sub-district level in electronic form. 


\section{Commercial Taxes}

The MMP, which aims at providing electronic services to commercial tax payers, is being formulated. The consultation process with the states is on-going and ministry of finance has been asked to expedite the consultation process for taking it to the next logical stages and initiate implementation on ground.

\section{Gram Panchayat}

The three basic pillars including common service centre (CSC), Stat wide area Network (SWAN), State Data Centers (SDC) supposed to be common for all projects under the NeGP umbrella. It is being created in every states and union territory to ensure a single window delivery of public services to the common man.

\section{II. e-Governance initiatives in Assam}

With regard to Assam, the state government has initiated many e-governance projects including Electoral Rolls computerizations system, BPL list, Pass port computerization system, computerization of land record system, Prithvi Geographical information system, Griha Lakshmi computerized public distribution system, online tender information system, pay- roll computerization system etc.

The e-District project is an important enhancement of the state's e-governance implementation of programme. This project is a Mission Mode Project (MMP) under National e-governance plan (NeGP) founded by government of India. The government of Assam has chosen two districts Sunitpur and Goalpara for the pilot implementation of the project. E-district provides support to the district administration to enable the citizen centric services, which would optimally utilize the Assam state wide area Network (ASWAN) and state data center at Guwahati to deliver services to the stake holders.

Assam has been placed in the category of "Expectant" on e-readiness index. Assam has shown a tremendous potential towards realization of its goal of getting transformed into an IT governed state. The fact is also supported by the e-readiness report 2008 , which shows that the state has made a remarkable improvement in its e-readiness ranking. It has moved up from level 5 in 2006 to level 3 in 2008.

Among the core infrastructure projects under NeGP, SWAN, SDC (State Data Centers) and CSC (Common service center) are being implemented in the state. Under the CSC scheme, 4375 common services centers will be established in Assam.

\section{The key e-governance project operating in Assam are-}

1. VIDHAN or Magistracy case Management system-it manages various magistracy cases and generates reports.

2. UDYOGRATNA-it is an effectual tool for monitoring the district industries centers (DICs).

3. PRITHVI GEOGRAPHICAL SYSTEM- all district boundaries of Assam have been digitized.

4. PARISHODH- computerized loan payment system.

5. ANUSHARAWAN-computerized circle office to DC office monthly reporting system.

6. MANAB SAMPAD-computerized personnel information management system.

7. GRIHA-LAKSHMI-computerized public distribution system.

8. NATHI-AWASTHITI or computerized file monitoring system-it's a file monitoring system that tracks the movement of files in various government departments.

9. SAPATH-Affidavits Management system.

Assam Electronic Development Corporation Limited (AMTRON) is a nodal agency of government of Assam for the implementation of various state level and national level projects these are ARBAS, ASWAN, CSC, SDC etc. AMTRON in collaboration with BSNL have organized various state level awareness programmes. It for their initiatives that many of our state government departments like tax, agriculture, revenue, police power, municipal authority etc are starting e-governance project recently. Along with other e-ready states in the country Assam can bag the "Best e-government state Award and e-ready state Award."

\section{Significance of e-governance projects in Assam-}

E-governance or digital governance is a center of attention of all the countries in the world in contemporary period. To accomplish the wishes of all the people is not an easy task for the government of developing countries. In this regard e-governance is the right track to fulfill the demand of common people. As the core objectives of National e-governance plan (NeGP) is to "make all government services accessible to the common man in his locality through common service delivery outlet and ensure efficiency, transparency and accountability of services at affordable costs to realize the basic needs of common man." E-governance strengthens the process of relationship between Government to Government (G2G), Government to citizen (G2C), Government to Business (G2B), Government to Government (G2G). The effective use of IT (information technology in the government department will enhance the efficiency of government department to better service delivery to citizen, ushering transparency and accountability, empowering people through information, improve efficiency within government, reduce time consuming, reduce unnecessary government 
hierarchy, foster team culture, easier supervision, enforcing accountability, reduce manipulation, getting rid of red-tapism and so on. Corruption is a major issue in India and it adversely impacts the economic and social fabric in India. In this case e-governance is a powerful weapon in the hand of the government to control corruption. The center for media studies conducted a survey among 4,500 citizens of five states in IndiaHyderabad, Delhi, Mumbai, Calcutta and Chennai. The survey clearly states that the application of IT has brought down corruption in some key public service departments-electricity, passport. Water supply, urban development, banking and railways. The study also shows that the application of IT in government department reduces the power of middleman between government and citizens for whom people are free from paying bribe. Besides this, e-governance makes its possible for increasing participation of people in government activities. With the availability of information e-governance makes peoples participation in governance successful.

Out of 27 Mission mode projects several key e-governance projects are successfully operating in the states of India, including Assam. However all states in India have not equally achieved the benefit of e-projects. The states like Karnataka, Maharashtra, Tamilnadu, Kerala, Andhra Pradesh, West Bengal, and Rajasthan have achieved innumerable quality public service through e-governance. The e-projects which currently operating in this states are namely-Bhoomi (land record), Nondani(land registration), Khajane (computerization of treasuries), Therige, Agricultural price information, computerization of transport department, education department and treasury, e-banking, payment of online bills such as electricity, water, telephone bill etc.

In Assam, web-enabled land record computerization system, named "Dharitee" had started a pilot project in the Sonitpur district of Assam. The first phase of implementation of Dharitee started in Nagaon and Kamrup district (1993-94). In Its second phase (1998-1999) the government of India rolled out this project at 21 districts in Assam. Then in the year 2003-2004, the project went to its third phase (current phase) with the financial assistance from the department of information technology (DIT). The essence of computerization of Land record is felt urgently due to the loopholes existing in the manual record systems. The problems relating to manual land record system includes huge blocking of land records data updating in every district and circle offices, inconsistency in maintenance of record, time and cost consuming, delay in mutation workflow system processes and unreliable management information system(MIS). Regarding computerization of road and transport "Vahan \& Sarathi" are personalized in 4 DTO's viz Kamrup, Silchar, Jorhat and Sibsagar district in Assam. According to the news paper report of 75 village panchyats in Bongaigaon district e-panchyat have been launched. E-court project is also being implemented in Assam. Under this project laptop and laser painters were distributed to the judicial offices in Assam. The report provided by Assam Informatics center 2002, 218 community information centers (CICs) had been functional almost seven years. The biggest achievement of the community information centers (CICs) is that they make ICT penetration possible in rural North-east including rural Assam. Community information system in Assam is primarily dealing with the following issues.

- Organize basic ICT orientation training programmes.

- Develop elementary websites.

- Election processes such as voter data entry, assistance in poll party randomization and monitoring, results analysis.

- National projects such as bellow poverty level (BPL) data entry, National Rural Employment guarantee Act (NREGA) etc.

- Block development office activities and process.

The functioning of Assam Community Information centers (CICs) are going ahead in comparison to the other states in North-eastern region in India. On the other way, the community information centers earn more than two crore of rupees. The following data provides the current picture on the functioning of Community Information centers in Assam.

Percentage of CICs in Assam: 44.9\%

Revenue earned by Assam: 78\%

Savings of Assam CICs: 64\%

Persons who have visited Assam CICs: 62\%

Assam is one of the 14 states in the country, where e-district pilot project was implemented. As stated above the government of Assam had selected Goalpara and Sonitpur as pilot districts for Assam in November, 2009 and January, 2010 respectively. Assam is one of the first states in the country to have successfully implemented the pilot project in both the pilot district i.e. Sonitpur and Goalpara. Under this e-district project, 22 G2C (Government to Citizens) services has been finalized and out of which 16 services are currently delivered through Common Service Centers (CSCs). This service 


\begin{tabular}{|c|c|c|c|}
\hline \multicolumn{4}{|l|}{ Includes: } \\
\hline SL NO & SERVICE CATAGORY & SERVICES & REMARKS \\
\hline \multirow[t]{6}{*}{1} & \multirow[t]{6}{*}{ Certificates } & Permanent Residents certificates & Functional \\
\hline & & Senior citizen certificates & Functional \\
\hline & & Non-creamy layer certificates & Functional \\
\hline & & Land valuation certificates & Functional \\
\hline & & Bakizai clearance certificate & Functional \\
\hline & & Income certificate & Functional \\
\hline \multirow[t]{2}{*}{2} & \multirow[t]{2}{*}{ Permissions/orders } & Delayed birth registration & Functional \\
\hline & & Delayed death registration & Functional \\
\hline \multirow[t]{4}{*}{3} & \multirow[t]{4}{*}{ Certified copies } & Certified copy of electoral roll & Functional \\
\hline & & Certified copy of mutual order & Functional \\
\hline & & Certified copy of court order & Functional \\
\hline & & Certified copy of Jamanbandi & Functional \\
\hline \multirow[t]{3}{*}{4} & \multirow[t]{3}{*}{$\begin{array}{l}\text { Family identity card } \\
\text { services }\end{array}$} & Application for new FIC & $\begin{array}{l}\text { Back and } \quad \text { end } \\
\text { computerization not ready }\end{array}$ \\
\hline & & $\begin{array}{l}\text { Application for modification of } \\
\text { FIC }\end{array}$ & $\begin{array}{l}\text { Back and end } \\
\text { computerization not ready }\end{array}$ \\
\hline & & Application for duplicate of FIC & $\begin{array}{l}\text { Back and } \quad \text { end } \\
\text { computerization not ready }\end{array}$ \\
\hline \multirow[t]{2}{*}{5} & \multirow[t]{2}{*}{ Pension } & $\begin{array}{l}\text { Application for National old age } \\
\text { pension(NOAP) }\end{array}$ & $\begin{array}{l}\text { Back and } \quad \text { end } \\
\text { computerization not ready }\end{array}$ \\
\hline & & $\begin{array}{l}\text { Application National family } \\
\text { benefit scheme(NIFBs) }\end{array}$ & $\begin{array}{l}\text { Back and end } \\
\text { computerization not ready }\end{array}$ \\
\hline \multirow[t]{2}{*}{6} & \multirow[t]{2}{*}{ Right to information } & $\begin{array}{l}\text { Application for information under } \\
\text { RTI }\end{array}$ & Functional \\
\hline & & Application for first appeal & Functional \\
\hline 7 & Grievances & Application and status tracking & Functional \\
\hline
\end{tabular}

Before e-district project launched in Assam, Citizens had to travel to block or tahsil offices and district headquarters in order to avail simple services like certificates for income, caste, birth and death and domicile. The distances from village to these offices are between 15-25 K.M. The system was not only costly but also time consuming. The government department also had a huge pending of application. Without any effective mechanism the senior officials found it difficult to monitor the services smoothly and well in time. But after the implementation of e-district project, it makes possible to eliminate the need of an applicant to come to a public office through e-delivery. Now the application of e-district projects in Assam increases the efficiency of various government departments by providing seamless services to common people easily through electronic medium. Another positive development is that the e-delivery process eliminates the duplication of asking same information from an applicant. Because, once an applicant applies for a service, the applicant's details are stored in the database. If the applicant wants to apply for other services, the system will not ask the detail as the applicant already submitted for previous one. In the absence of voluminous files, now the administrator does not have to lead an extra burden and can perform his/her functions efficiently with the avail of digital records. Even, biometrics and password base log in reduces the chances of delayed approval. The life of citizens becomes easy, if government is able to offer multiple services delivery channels with $24 \times 7$ availability. The online transaction between government and citizen's will definitely increase citizen's convenience in accessing service.

\section{SAHAJ largest CSC network}

Sahaj is another unique e-governance citizen-centric service model, well functioning in several states in India including Assam. Till date Sahaj etched their presence across 1388 blocks of 107 districts in 6 States. The current Common Service Centers (CSCs) operating under Sahaj includes 1045 CSCs in Tamilnadu, 2833CSCs in Assam, 6797 CSCs in West Bengal, 5565 in Bihar, 8118 CSCs in Uttar Pradesh and 3648 CSCs in Orissa.

Integrity, trust, customer centricity, experimentation, accountability are upholding to be the core values in Sahaj e-governance projects. Sahaj aims to create the largest network by 2012 that would access over 250 million people. Sahaj tries to develop a podium that would entail government, private and social sector organizations to assimilate their social and commercial goals for the advantage of the rural population in the furthest areas of the 
country through a blend of IT and non-IT services. Sahaj wants to create the largest digital network not only in this country, but also catering to the expanding base of customers living in the remotest corner of the world by bridging efficient financial and humanitarian services to all of them. The main objectives of Sahaj includes-

(a) Making information and knowledge accessible-

Sahaj transmits information and knowledge. Just and equal distribution of knowledge and information is the prime goal of Sahaj in order to eradicate the digital divide problem.

(b) Generating and enhancing value by identifying, financing and developing growth business-

Sahaj works with governments, corporate and village level entrepreneurs (VLEs) to expand their market and bring value added services to the customers.

\section{(c) Government advisory services-}

Sahaj consultants from government and information technology sectors are culturally sentient and have the potential to deliver and to end solutions. These resourceful consultants bring the right experience and expertise to design the reference architectures and roadmaps to achieve e-governance objectives.

Till date, Sahaj undertake numerous citizen-centric services. It includes-

G2C: (Government to citizen services)

E-district services in Assam, Bihar, UP \& Tamilnadu

- Birth and death certificates.

- Income certificates.

- PRC/ domicile certificate.

- Caste certificate.

- Certified copy of electoral roll.

- Government forms submission.

- Saakshar Bharat data entry work.

- NRHM data entry \& MIS posting.

- Commercial data entry \& MIS posting.

- Commercial Tex services.

- Training to elected PRI representatives.

- Awareness programme regarding NeGP among VLEs \& students.

\section{Financial Services:}

- Business correspondent.

- $\quad$ Life \& Non-life insurance service.

Utility Services:

- Power bill payment.

- BSNL bill payment.

Business Development and Emerging Business:

- Two wheelers booking.

- Railway reservations.

- Flight booking.

- Affinity marketing.

- Retail scales.

Future Services:

- DTH research and booking.

- e-commerce.

- Agriculture Diagnostics.

- Distance education.

- IEC (information, education and communication).

- Infotainment.

\section{Challenges of e-governance in Assam-}

Our study finds several challenges before successful working of e-governance in Assam. We have divided it into two categories- (1) Front end challenges and (2) Back end challenges. The former category includes (Front end challenges)- low rate of literacy, inadequate power supply, low broadband penetration, absence of user friendly interface, dearth of training manpower and lack of awareness. The later category of 
challenges (Back end challenges) includes- lack of interoperability, resistance to change, poor projects planning and implementation, lack of defined outcomes and measurement mechanism, inadequate data safety, partial online execution services. If government is able to overcome these loopholes, we can expect a better Assam and a brighter India.

In conclusion, the benefits of e-governance can be summarized as follows-

- Convenient and cost effective service delivery.

- Transparency, accountability and efficiency of service delivery.

- Reduced corruption.

- Increased participation by people.

- Balanced development.

- Improve the quality of life for citizens.

- Reduce time and cost.

- Increase velocity of business.

- Promote good governance.

\section{References}

[1] "E-Governance: an overview in the Indian context", Sumanjeet, vol- IXVII, IJPS, Dec, 2006.

[2] "Introducing e-governance: History, definitions and issues", Ake Gronlund, Orebro University, communication of the Association for information system, Volume 15, 2004.

[3] "Right to information as a too to promote and strengthen democracy", Dr. Padmarani, Global Media Journal, Dec, 2010.

[4] "Effective e-governance for good governance in India", N.S.Kalsi, Ravi Kiran and S.C Vaidya, International Review of Business Research papers, Vol-V, $1^{\text {st }}$ January, 2003.

[5] "Role of e-governance in Tackling corruption and achieving societal harmony: Indian Experience", Dr. R.D. Pathak, Dr. R.S. Prasad, Beijing, Dec, 2005.

[6] "Lesson from e-government initiatives in Uttar Pradesh," Shefali Nandan, Allahabad, India.

[7] " $15^{\text {th }}$ National conference on e-governance Award, Bhubaneswar, Odisha, 2012.

[8] "e-districts cuts through red tapism citizen service delivery", Pratap Vikram Singh, April, 2012.

[9] "ICT and e-governance: A complete overview", Monika Gupta, journal of information and operations management.

[10] "A new public management perspective in Indian e-governance initiative", Gyan Prakash, Avantika Singh.

[11] "E-government and e-governance: Definitions framework and status around the world", Shailendra C. Jain, Sushil S. Sharma.

[12] "Prospects of e-governance in India", Punnet Kumar, pratik Bharti, International journal of engineering and innovative Technology (IJEIT), volume-2, Sep, 2012

[13] "Grassroots ICT projects in India: some preliminary hypothesis", Kenneth Keniston, ASCI journal of management, 2002.

[14] Satyanarayan, J, "E-government: The Science of the possible", New Delhi, PHI learning Pvt ltd, 2010.

[15] Pani, Niranjan, Mishra.s.Santap, Sahu.s.Bijaya, "Modern system of governance (Good governance vs. e-governance), Amol publication Pvt Ltd, New Delhi, 2004.

[16] "E-governance: concepts and case studies", Prabhu, CSR.

[17] "The eleventh Report second administrative reform commission: promoting e-governance the SMART way forward" December, 2008. 